\title{
Interleukin-1 Enhances the ATP-Evoked Release of Arachidonic Acid from Mouse Astrocytes
}

\author{
Nephi Stella, ${ }^{1,2}$ Angeles Estellés, ${ }^{1}$ Julio Siciliano, ${ }^{1}$ Martine Tencé, ${ }^{1}$ Solange Desagher, ${ }^{1}$ Daniele Piomelli, ${ }^{2}$ \\ Jacques Glowinski, ${ }^{1}$ and Joël Prémont ${ }^{1}$ \\ 1 Laboratoire de Neuropharmacologie, Institut National de la Santé et de la Recherche Médicale U114, Collège de France, \\ 75231 Paris Cedex 05, France, and ${ }^{2}$ The Neurosciences Institute, San Diego, California 92121
}

During neuropathological states associated with inflammation, the levels of cytokines such as interleukin-1 $\beta(\mathrm{IL}-1 \beta)$ are increased. Several studies have suggested that the neuronal damage observed in pathogenesis implicating $\mathrm{IL}-1 \beta$ are caused by an alteration in the neurochemical interactions between neurons and astrocytes. We report here that treating striatal astrocytes in primary culture with IL-1 $\beta$ for 22-24 hr enhances the ATP-evoked release of arachidonic acid (AA) with no effect on the ATP-induced accumulation of inositol phosphates. The molecular mechanism responsible for this effect involves the expression of $\mathrm{P}_{2 \mathrm{Y} 2}$ receptors (a subtype of purinoceptor activated by $A T P)$ and cytosolic phospholipase $A 2\left(\mathrm{CPLA}_{2}\right.$, an enzyme that mediates $A A$ release). Indeed, $P_{2 Y 2}$ antisense oligonucleotides reduce the ATP-evoked release of $A A$ only from IL-1 $\beta$-treated astrocytes. Further, both the amount of CPLA2 (as assessed by Western blotting) and the release of AA resulting from direct activation of $\mathrm{CPLA}_{2}$ increased fourfold in cells treated with $\mathrm{IL}-1 \beta$. We also report evidence indicating that the coupling of newly expressed $\mathrm{P}_{2 \mathrm{Y} 2}$ receptors to $\mathrm{CPLA}_{2}$ is dependent on PKC activity. These results suggest that during inflammatory conditions, IL-1 $\beta$ reveals a functional $\mathrm{P}_{2 \mathrm{Y} 2}$ signaling pathway in astrocytes that results in a dramatic increase in the levels of free AA. This pathway may thus contribute to the neuronal loss associated with cerebral ischemia or traumatic brain injury.

Key words: purinoceptor; phospholipase; cytokine; inflammation; glutamate; neurotoxicity
ATP acts both as an intracellular source of energy and an intercellular signaling molecule. Several studies carried out in smooth muscle nerve endings, peripheral ganglia, and brain have shown that ATP is (1) stored in neuronal vesicles; (2) released in a $\mathrm{Ca}^{2+}$-dependent manner; (3) able to activate specific receptors; and (4) hydrolyzed by ecto-ATPases (for review, see Zimmermann, 1994). By way of illustration, it is present in synaptic vesicles of cholinergic interneurones of the striatum where it is co-localized and co-released with acetylcholine (Richardson and Brown, 1987).

This purine binds to and activates a family of purinoceptors $\left(\mathrm{P}_{2}\right.$ receptors) namely $\mathrm{P}_{2 \mathrm{X}}, \mathrm{P}_{2 \mathrm{Y}}, \mathrm{P}_{2 \mathrm{U}}, \mathrm{P}_{2 \mathrm{Z}}$, and $\mathrm{P}_{2 \mathrm{~T}}$, which have been classified based on the potencies of structural ATP analogs (Fredholm et al., 1994). For most of them, cDNAs have been cloned and characterized (Lustig et al., 1993; Webb et al., 1993, 1996; Communi et al., 1995; Nguyen et al., 1995; Chang et al., 1995; Akbar et al., 1996). It was recently recommended that the $\mathrm{P}_{2 \mathrm{X}} /$ $\mathrm{P}_{2 \mathrm{Y}}$ division be used to distinguish between members of this receptor family that are ligand-gated ion channels or G-proteincoupled receptors, respectively. Accordingly, an official nomenclature of $\mathrm{P}_{2 \mathrm{Y} 1}-\mathrm{P}_{2 \mathrm{Yn}}$ has been assigned for the $\mathrm{G}$-protein-coupled receptors, whereas $\mathrm{P}_{2 \mathrm{Y} 2}$ receptors correspond to the formerly $\mathrm{P}_{2 \mathrm{U}}$ receptor.

ATP has been implicated in neuro-neuronal communication (Edwards et al., 1992; Evans et al., 1992; Galligan and Bertrand,

\footnotetext{
Received Jan. 2, 1997; revised Feb. 5, 1997; accepted Feb. 10, 1997.

We wish to express our gratitude to Drs. Jean-Antoine Girault, Stephen Jenkinson, and Joe Gally for helpful suggestions.

Correspondence should be addressed to Dr. Nephi Stella, The Neurosciences Institute, 10640 John J. Hopkins Drive, San Diego, CA 92121

Copyright (C) 1997 Society for Neuroscience 0270-6474/97/172939-08\$05.00/0
}

1994), as well as in neuro-glial interactions. Indeed, activation of purinoceptors present in primary cultures of rat astrocytes leads to the accumulation of inositol phosphate derivatives (Pearce et al., 1989; Kastritsis et al., 1992; Salter and Hicks, 1994) and to the release of AA (Gebicke-Haerter et al., 1988; Pearce et al., 1989; Bruner and Murphy, 1990). Stimulation of second messenger pathways by ATP is thought to regulate several properties of astrocytes, some of which may be involved in mechanisms of neural injury (Enkvist and McCarthy, 1992; Christjanson et al., 1993; Abbracchio et al., 1994; Neary et al., 1994; Sorg et al., 1995).

Various cytokines and growth factors are produced in the CNS under pathological conditions (e.g., bacterial or viral infections and neurodegenerative diseases) and participate in the remodeling of the affected area (Perry et al., 1993). One such cytokine, IL- $1 \beta$, which is primarily present in activated microglia or invading macrophages (Giulian et al., 1986; Hertier et al., 1988; Woodroofe et al., 1991) binds to high-affinity interleukin-1 (IL-1) receptors and induces a large variety of cellular responses (Dinarello, 1994). At low concentrations (in the pM range), IL-1 $\beta$ binds to receptors present on astrocytes (Ban et al., 1993) and induces the expression of various genes (Benveniste et al., 1990; Negro et al., 1992; Théry et al., 1992; Das and Potter, 1995). In particular, IL-1 $\beta$ has been shown to enhance the amounts of both secreted and cytosolic phospholipase A2 isoenzymes ( $\mathrm{SLA}_{2}$ and cPLA ${ }_{2}$ ) (Oka and Arita, 1991; Ozaki et al., 1994). This process may be responsible for the enhanced release of eicosanoids from astrocytes after cytokine treatment (Yamamoto et al., 1988; Katsuura et al., 1989).

Based on these observations, the present study was undertaken to determine whether IL- $1 \beta$ modifies the second messenger signaling pathways stimulated by ATP. We have found that treating 
primary cultures of striatal astrocytes for $22-24 \mathrm{hr}$ with IL-1 $\beta$ enhances the ATP-evoked release of AA. The molecular mechanisms involved in the effect of the cytokine implicate both the induction of $\mathrm{P}_{2 \mathrm{Y} 2}$ receptors and an increase in the amount of CPLA $_{2}$. Therefore, by promoting the expression of these two proteins, IL- $1 \beta$ reveals a functional $\mathrm{P}_{2 \mathrm{Y} 2}$ signaling pathway that is absent in untreated astrocytes.

\section{MATERIALS AND METHODS}

Poly-L-ornithine (MW, 30,000-70,000), fatty acid-free BSA, ATP, UTP, 2MeS-ATP, thimerosal, pyruvate, PMA, histone III-S, phosphatidylserine, diolein, and human recombinant interleukin-6 (IL-6) were obtained from Sigma (St. Louis, MO); leupeptin, aprotinin, N-[1-(2,3-dioleoyloxy) propyl]N,N, $N$-trimethylammonium methylsulfate (DOTAP), adenosine deaminase (ADA), and glutamate-pyruvate transaminase (GPT) from Boehringer Mannheim (Mannheim, Germany); $\left[{ }^{3} \mathrm{H}\right]$ arachidonic acid ([ $\left.\left.{ }^{3} \mathrm{H}\right] \mathrm{AA}, 8.25 \mathrm{TBq}\right)$, myo-[2- $\left.{ }^{3} \mathrm{H}\right]$ inositol with PTG-271 $(633 \mathrm{GBq} / \mathrm{mmol})$, $\left[\gamma^{32} \mathrm{P}\right]$ ATP $(111 \mathrm{TBq} / \mathrm{mmol})$, Hybond C-ECL nitrocellulose membranes, HRP-coupled anti-rabbit IgG antibodies and ECL reagent from Amersham (Arlington Heights, IL); autoradiographic films (Cronex) from Dupont (Wilmington, DE); MEM and F-12 nutrient from Life Technologies; Nu-Serum from Collaborative Research; human recombinant interleukin-1 $\beta$ (IL-1 $\beta$, Saxon, CA); human recombinant interleukin- $1 \alpha$ (IL-1 $\alpha$ ) from Biosource International, Camarillo, CA, and oligonucleotides from GENSET, Paris, France. Rabbit anti-phospholipase A2 was a gift from L.-L. Lin, Genetics Institute, Cambridge, MA (Clark et al., 1991).

Cell culture. Primary cultures of striatal astrocytes were prepared as described previously (El-Etr et al., 1989). Briefly, striata were removed from 16-d-old Swiss mouse embryos (Iffa Credo, Lyon, France). Mechanically dissociated cells were plated $(200,000 \mathrm{cells} / \mathrm{ml})$ on either 12-well Falcon culture dishes $(1 \mathrm{ml} /$ well $)$ or $90 \mathrm{~mm}$ dishes $(12.5 \mathrm{ml} / \mathrm{dish})$, previously coated with $1.5 \mu \mathrm{g} / \mathrm{ml}$ polyornithine. The culture medium consisted in a mixture of MEM and F-12 nutrient (1:1) supplemented with $33 \mathrm{~mm}$ glucose, $2 \mathrm{~mm}$ glutamine, $13 \mathrm{~mm} \mathrm{NaHCO}_{3}, 5 \mathrm{~mm}$ HEPES, $\mathrm{pH}$ 7.0, and 5\% Nu-serum. Cells were cultured at $37^{\circ} \mathrm{C}$ for $18-21 \mathrm{~d}$ in a humidified atmosphere of $95 \%$ air $/ 5 \%$ $\mathrm{CO}_{2}$. The culture medium was first changed on day 7 , and cytosine arabinoside $(2 \mu \mathrm{M})$ was added for $72 \mathrm{hr}$ to avoid the formation of cell multilayers and the proliferation of microglia. On day 10, cells were rinsed once with PBS containing $33 \mathrm{~mm}$ glucose (PBSglc) and fresh culture medium was added. Thereafter, the culture medium was changed on days 14 and 17. Under these conditions, after $21 \mathrm{~d}$ in culture, $>95 \%$ of the cells were stained by the indirect immunofluorescence technique using a rabbit antibody against GFAP (ICN, Costa Mesa, CA). The remaining 5\% of the cells could be immature glioblasts, which are known to be unlabeled by GFAP antibodies (Cameron and Rakic, 1991). Cultures were devoid of microglial cells and neurons, because no immunostaining was observed using the monoclonal anti-mouse macrophage antibody anti-MAC 1 (Serotec) (Frei et al., 1987) and the anti-neurofilament-triplet antibodies (kindly provided by Dr. R. K. Liem, Columbia University), respectively (see Marin et al., 1993).

Measurement of $\left[{ }^{3} \mathrm{H}\right] \mathrm{AA}$ release. The release of $\left[{ }^{3} \mathrm{H}\right] \mathrm{AA}$ was measured as described previously (Stella et al., 1994) with slight modifications. Briefly, astrocytes cultured in 12-well dishes were labeled for 22-24 hr in a fresh culture medium containing $\left[{ }^{3} \mathrm{H}\right] \mathrm{AA}(1 \mu \mathrm{Ci} / \mathrm{ml})$. Cells were then washed three times at $37^{\circ} \mathrm{C}$ with Locke-HEPES buffer (L-H buffer; 1 $\mathrm{ml} /$ well) containing (in $\mathrm{mm}$ ): $\mathrm{NaCl} 145, \mathrm{KCl} 5.5, \mathrm{CaCl}_{2} 1.1, \mathrm{MgCl}_{2} 1.1$, $\mathrm{NaHCO}_{3} 3.6$, glucose 5.5, HEPES 20, pH 7.4, supplemented with fatty acid-free BSA $(1 \mathrm{mg} / \mathrm{ml})$. Cells were then preincubated for $10 \mathrm{~min}$ in the same medium containing thimerosal $(50 \mu \mathrm{M})$ to inhibit AA reacylation (see Stella et al., 1994) and the adenosine degrading enzyme ADA (1 $\mathrm{IU} / \mathrm{ml}$ ) to prevent any possible modulating effect of endogenous adenosine (El-Etr et al., 1989). Cells were then exposed to the effectors for 15 min at $37^{\circ} \mathrm{C}$ in the same medium supplemented with GPT (5 IU) and 1 $\mathrm{mm}$ pyruvate to prevent the potentiation of the ATP-evoked release of AA by endogenous glutamate (Stella et al., 1994). Incubation media were recovered and centrifuged for $5 \mathrm{~min}$ at $200 \times g$ to eliminate nonadherent cells, and the radioactivity was estimated in the supernatant. HPLC analysis, performed as described previously (Delumeau et al., 1991), indicated that $>95 \%$ of the radioactivity is recovered in a peak having the same retention time as authentic AA.

Measurement of $\left[{ }^{3} H\right]$ phospholipids by TLC. After 22-24 hr of labeling with $\left[{ }^{3} \mathrm{H}\right] \mathrm{AA}$, cells were washed three times with PBSglc. Ice-cold methanol $(0.5 \mathrm{ml})$ containing $2 \%$ acetic acid was then added, cells were scraped off with a rubber policeman, culture dishes were rinsed twice with $0.5 \mathrm{ml}$ methanol, and lysates were sonicated for $5 \mathrm{~min}$. Lipids were extracted by adding $1.5 \mathrm{ml}$ of $\mathrm{CHCl}_{3}, 0.8 \mathrm{ml}$ of $\mathrm{H}_{2} 0$, and $20,000 \mathrm{dpm}$ of 1,2-di $\left[{ }^{14} \mathrm{C}\right]$ palmitoyl-phosphatidylcholine $(112 \mathrm{mCi} / \mathrm{mmol})$ to the combined methanolic solution of two dishes. The monophase was shaken and left for several hours at $4^{\circ} \mathrm{C}$. $\mathrm{CHCl}_{3}$ and $\mathrm{H}_{2} \mathrm{O}(1.5 \mathrm{ml}$ each; both ice-cold $)$ were then added to disrupt the phases. Extracts were again vigorously shaken and left at $4^{\circ} \mathrm{C}$ overnight for the ensuing layers to separate. Aliquots of the lower $\mathrm{CHCl}_{3}$ phase were counted to determine the radioactivity, and this was used as an index of the phospholipid extraction efficiency. After extraction, lipids were dried, resuspended in $\mathrm{CHCl}_{3} /$ $\mathrm{CH}_{3} \mathrm{OH}$ solution (5:1), and spotted on silica gel plates 60 (F254, Merck, Darmstadt, Germany) previously activated at $100^{\circ} \mathrm{C}$ for $30 \mathrm{~min}$. Phospholipids were separated by bidimensional TLC with $\mathrm{CHCl}_{3} / \mathrm{CH}_{3} \mathrm{OH} / \mathrm{NH}_{4}$ $(25 \%) / \mathrm{H}_{2} \mathrm{O}$ (87:52:5:5 by volume) and $\mathrm{CHCl} / \mathrm{CH}_{3} \mathrm{OH} /$ acetic acid $/ \mathrm{H}_{2} \mathrm{O}$ (94:42:12:2 by volume). Spots were visualized with iodine vapor by using standards of the major phospholipids, and radioactivity was determined with $10 \mathrm{ml}$ of Aquasol 2.

Measurement of $\left[{ }^{3} H\right]$ inositol phosphate $\left(\left[{ }^{3} H\right] I P\right)$ formation. The accumulation of $\left[{ }^{3} \mathrm{H}\right] \mathrm{IP}$ was measured as previously described (Stella et al., 1994) with slight modifications. Briefly, astrocytes cultured in 12-well dishes were incubated for $22-24 \mathrm{hr}$ in a fresh culture medium containing myo- $\left[{ }^{3} \mathrm{H}\right]$ inositol $(2 \mu \mathrm{Ci} / \mathrm{ml})$. Cells were washed three times with $\mathrm{L}-\mathrm{H}$ buffer at $37^{\circ} \mathrm{C}$ and then preincubated for $10 \mathrm{~min}$ in L-H buffer supplemented with lithium $(10 \mathrm{~mm})$ and ADA $(1 \mathrm{IU} / \mathrm{ml})$. Cells were then exposed to the effectors for $15 \mathrm{~min}$ at $37^{\circ} \mathrm{C}$ in the same medium supplemented with GPT (5 IU) and pyruvate $(1 \mathrm{~mm})$. The incubation was stopped by adding successively $0.1 \%$ Triton X-100 in $0.1 \mathrm{M} \mathrm{NaOH}(400$ $\mu \mathrm{l})$ and $0.1 \%$ Triton $\mathrm{X}-100$ in $0.1 \mathrm{M} \mathrm{HCl}(400 \mu \mathrm{l})$. Lysates were recovered, and $\left[{ }^{3} \mathrm{H}\right] \mathrm{IPs}$ were then extracted and estimated as described previously (El-Etr et al., 1989).

$R N A$ isolation and reverse transcriptase polymerase chain reaction (RT) $P C R)$. RNA was isolated from untreated or IL- $1 \beta$-treated astrocytes grown in $90 \mathrm{~mm}$ dishes by lysing the cells with guanidium isothiocyanate and subsequent extraction with acidified phenol and chloroform (1:1) (Chomczynski and Sacchi, 1987). After total RNA extraction, first-strand DNA synthesis was performed with Avian Myeloblastosis Virus reverse transcriptase (AMVRT, Boehringer Mannheim) after priming with an oligo-(dT) $)_{18}$. The reaction mixture contained $50 \mathrm{~mm}$ Tris, $30 \mathrm{mM} \mathrm{KCl}, 8$ $\mathrm{mM} \mathrm{MgCl}_{2}, 1 \mathrm{~mm}$ dithiothreitol, $0.1 \% \mathrm{BSA}, 25 \mathrm{IU}$ of RNase inhibitor, and 0.4 mM dATP, dCTP, dTTP, and dGTP. The cDNA was used as template in a PCR containing two $\mathrm{P}_{2 \mathrm{Y} 2}$-specific oligonucleotides: GACCTGGAACCCTGGAATAGCACCA and CTCCCCAGGCACCGGTGCACGCTGAT, sense and antisense corresponding to amino acid 4-13 and 126-136, respectively. Mouse genomic DNA was used as a positive control. Cycling parameters were $94^{\circ} \mathrm{C}$ for $30 \mathrm{sec}, 57^{\circ} \mathrm{C}$ for $45 \mathrm{sec}$, and $70^{\circ} \mathrm{C}$ for $1 \mathrm{~min}$ for 30 cycles and a final incubation at $72^{\circ} \mathrm{C}$ for $10 \mathrm{~min}$. Amplified products were resolved by agarose gel electrophoresis. The 396 bp PCR product was isolated from the gel (Qiaex extraction kit, Qiagen, Hilden, Germany), inserted into the PCRII vector using the TA cloning kit (Invitrogen, San Diego, CA) and sequenced using modified T7 polymerase (sequenase kit, Amersham).

Oligodeoxynucleotide treatment. The antisense phosphorothioate oligodeoxynucleotides (Genset SA) $\mathrm{P}_{2 \mathrm{Y} 2}$-AS 5'-CAG GTC TGC TGC CAT $-3^{\prime}$ and the scrambled phosphorothioate oligodeoxynucleotides $\mathrm{P}_{2 \mathrm{Y} 2}$-SCR 5'-GTG CCT GTA CGT ACC-3' were used to treat the cells. Astrocytes cultured in 12-well dishes were incubated for $8 \mathrm{hr}$ with a fresh culture medium containing oligodeoxynucleotides $(10 \mu \mathrm{g})$ and DOTAP $(10 \mathrm{mg} / \mathrm{ml})$. DOTAP was applied to enhance the uptake of oligodeoxynucleotides into the cells (Bennet et al., 1992; Capaccioli et al., 1993). $\left[{ }^{3} \mathrm{H}\right] \mathrm{AA}(1 \mu \mathrm{Ci} /$ well $)$ and cytokines were then added to the cells for $22-24 \mathrm{hr}$.

Measurement of protein kinase $C(P K C)$ activity. Astrocytes grown in 90 $\mathrm{mm}$ dishes were washed three times with ice-cold PBSglc and then scraped into $5 \mathrm{ml}$ of lysis buffer containing (in $\mathrm{mm}$ ): $10 \mathrm{MgCl}_{2}, 2$ EDTA, 0.5 EGTA, 1 phenyl methyl sulfonyl fluoride, 5 dithiothreitol, as well as $10 \mu \mathrm{g} / \mathrm{ml}$ leupeptin, $10 \mu \mathrm{g} / \mathrm{ml}$ aprotinin, and $20 \mathrm{~mm}$ Tris- $\mathrm{HCl}, \mathrm{pH}$ 7.4. Unless otherwise stated, all following procedures were performed at $4^{\circ} \mathrm{C}$. Cell suspension was homogenized with a loose-fitting glass-glass Dounce homogenizer and centrifuged for $12 \mathrm{~min}$ at $180,000 \times \mathrm{g}$. Supernatant (cytosolic fraction) was retained, and the pellet (membrane fraction) was resuspended by homogenization into $5 \mathrm{ml}$ of lysis buffer, stirred with $1 \%$ Nonidet P-40 for $1 \mathrm{hr}$, and then centrifuged for $12 \mathrm{~min}$ at $180,000 \times \mathrm{g}$. Resulting detergent-solubilized membranes and cytosolic fractions were applied to DE-52 columns $(1 \mathrm{ml})$ previously equilibrated with the lysis 
buffer. Columns were then washed with $6 \mathrm{ml}$ of lysis buffer, and PKC was eluted with $2 \mathrm{ml}$ of lysis buffer supplemented with $150 \mathrm{~mm} \mathrm{NaCl}$. PKC activities in the cytosolic and membrane fractions (30 $\mu \mathrm{l}$ DE-52 eluate) were assayed in a $20 \mathrm{~mm}$ Tris- $\mathrm{HCl}$ buffer, $\mathrm{pH} 7.4$, with $10 \mathrm{mM} \mathrm{MgCl}_{2}, 1.5$ $\mathrm{mM} \mathrm{CaCl}, 0.8 \mu \mathrm{g}$ diolein, and $5 \mu \mathrm{g}$ phosphatidylserine (total volume 100 $\mu \mathrm{l})$ with $50 \mu \mathrm{g}$ histone III-S as substrate. The reaction was started by adding $10 \mu \mathrm{l} \gamma-\left[{ }^{32} \mathrm{P}\right] \mathrm{ATP}(100 \mu \mathrm{M}, 0.5 \mu \mathrm{Ci} /$ assay $)$, performed at $30^{\circ} \mathrm{C}$ for $10 \mathrm{~min}$ (the reaction is linear for $10 \mathrm{~min}$ ) and stopped by adding $20 \mu \mathrm{l}$ ice-cold phosphoric acid $(150 \mathrm{mM})$. Histones were retained on ionexchange filters (Watman P-81). PKC activity was defined as the difference between $\left[{ }^{32} \mathrm{P}\right]$ incorporated into histones in the presence or absence of calcium, phosphatidylserine, and diolein and was expressed as total nanomoles of ATP incorporated into histones during a $10 \mathrm{~min}$ incubation. Protein concentrations were measured according to the method described by Bradford (1976) using BSA as standard. Treatment with IL-1 $\beta$ for 22-24 hr did not significantly change the total protein content of astrocytes per well.

$c P L A_{2}$ analysis by Western blotting. After a typical $\left[{ }^{3} \mathrm{H}\right] \mathrm{AA}$ release experiment, the incubation L-H buffer medium was removed, cells were solubilized in $1 \%$ (wt/vol) SDS, and the homogenate was boiled for $5 \mathrm{~min}$. Protein concentration was determined with a bicinchoninic acid method (Smith et al., 1985) using BSA as standard. Samples containing equal amounts of proteins $(100 \mu \mathrm{g})$ were mixed with Laemmli sample buffer (Laemmli, 1970) and loaded onto $8 \%$ (wt/vol) polyacrylamide gels for SDS-PAGE. Proteins were transferred electrophoretically to nitrocellulose sheets (Towbin et al., 1979). Immunoblot analysis was performed with rabbit anti-cPLA 2 antibodies in $150 \mathrm{~mm} \mathrm{NaCl}, 5 \%$ (wt/vol) free-fat dry milk and $50 \mathrm{~mm}$ Tris- $\mathrm{HCl}, \mathrm{pH}$ 7.4. Immunoreactivity was detected with ECL (New England Nuclear, Boston, MA) using HRP-coupled donkey anti-rabbit secondary antibodies (Amersham). Immunoreactive bands were quantified using a computer-assisted densitometer (IMSTAR, Paris, France).

Statistical analysis. Results are expressed in (percent of the control ATP response), where data $=$ response in the presence of all the agents tested - corresponding basal AA response (i.e., in the absence of ATP)/response evoked by $200 \mu \mathrm{M}$ ATP from untreated cells - basal AA release from untreated cells. Data are expressed as mean \pm SEM of $n$ independent determinations and were statistically analyzed using InStat (GraphPad Software, San Diego, CA).

\section{RESULTS}

\section{Activation of IL-1 receptors enhances the ATP-evoked release of $\left[{ }^{3} \mathrm{H}\right] \mathrm{AA}$}

ATP stimulated the release of $\left[{ }^{3} \mathrm{H}\right] \mathrm{AA}$ from striatal astrocytes in primary culture (Fig. 1) (Stella et al., 1994). Treatment of astrocytes for 22-24 hr with increasing concentrations of IL- $1 \beta$ enhanced the release of $\left[{ }^{3} \mathrm{H}\right] \mathrm{AA}$ evoked by the maximally effective concentration of ATP $(200 \mu \mathrm{M})$ (Fig. 1). IL-1 $\beta$ treatment enhanced basal $\left[{ }^{3} \mathrm{H}\right] \mathrm{AA}$ release by only $40 \%$ (Fig. 1 ), whereas it induced a doubling of the ATP response (Fig. $2 A$ ). The ATPevoked release of $\left[{ }^{3} \mathrm{H}\right] \mathrm{AA}$ was not changed when IL-1 $\beta$ (100 pM) was applied simultaneously with ATP (Table 1).

Involvement of IL-1 receptors was demonstrated by using the IL-1 receptor antagonist protein IL-1ra (Hannum et al., 1990). IL-1ra $(10 \mathrm{~nm})$ completely prevented the enhancing effect of IL- $1 \beta$ on the ATP-evoked release of $\left[{ }^{3} \mathrm{H}\right] \mathrm{AA}$ (Table 1 ) as well as its small effects on basal $\left[{ }^{3} \mathrm{H}\right] \mathrm{AA}$ release (data not shown). IL- $1 \alpha$, which is also an agonist of IL-1 receptors (Sims et al., 1988), reproduced the enhancing effect of IL-1 $\beta$ on the ATP response (Table 1). Furthermore, as expected for two cytokines acting on common IL- 1 receptors, enhancing effects of IL- $1 \alpha$ and IL- $1 \beta$ were not additive (Table 1). It has been described previously that astrocytes produce and secrete IL-6 in response to IL- $1 \beta$ (Benveniste et al., 1990); therefore, we examined whether IL-6 could account for the effect of IL- $1 \beta$. However, IL- 6 did not change the ATP-evoked release of $\left[{ }^{3} \mathrm{H}\right]$ AA (Table 1).

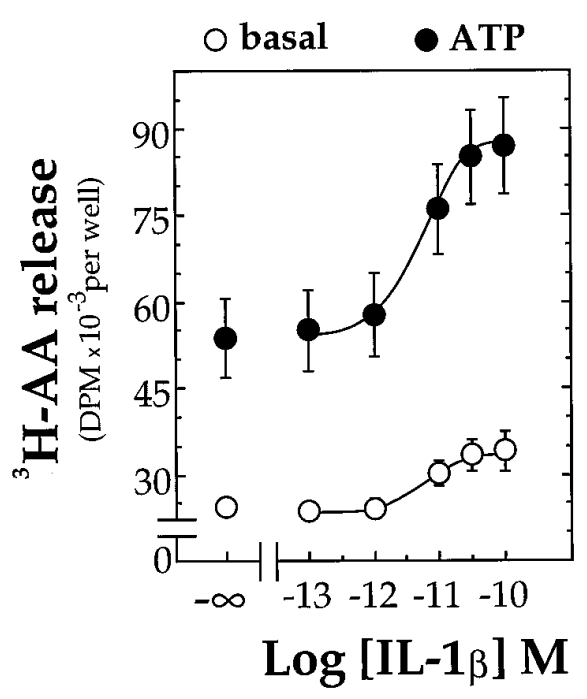

Figure 1. Effect of increasing concentrations of IL-1 $\beta$ on the ATPevoked release of $\left[{ }^{3} \mathrm{H}\right] \mathrm{AA}$ from striatal astrocytes. Striatal astrocytes were treated for 22-24 hr with increasing concentrations of IL- $1 \beta$ and then $\left[{ }^{3} \mathrm{H}\right] \mathrm{AA}$ release was estimated during $15 \mathrm{~min}$ in the absence (basal) or presence of ATP $(200 \mu \mathrm{M})$, as described in Materials and Methods. Each data point corresponds to the mean \pm SEM of $n=12$ determinations from four independent experiments performed in triplicate. The $\mathrm{EC}_{50}$ for $\mathrm{IL}-1 \beta$ is $\approx 5 \mathrm{pM}$.

$\begin{aligned} & \text { Table 1. Activation of the IL-1 receptor enhances the ATP-evoked } \\ & \text { release of }\left[{ }^{3} \mathbf{H}\right] \text { AA }\end{aligned}$

Astrocytes were treated for the indicated period with IL-1 $\beta$ (100 pM), IL-1 $\alpha$ (100 $\mathrm{pm})$, IL-6 (100 pM), and the IL-1 receptor antagonist IL-1ra $(10 \mathrm{nM}) .\left[{ }^{3} \mathrm{H}\right] \mathrm{AA}$ release evoked by ATP $(200 \mu \mathrm{M})$ was then estimated, as described in Materials and Methods. Each data point corresponds to the mean \pm SEM of $n=9$ determinations from three independent experiments performed in triplicate. Data are expressed in percent of the control ATP $(200 \mu \mathrm{M})$-evoked release of AA measured in the same experiment in - IL- $1 \beta$ cells. ${ }^{*} p>0.01$ : significantly different from the control ATP response (ANOVA followed by Dunnett's test).

\section{Activation of IL-1 receptors does not affect the ATP- induced accumulation of $\left[{ }^{3} \mathrm{H}\right] \mathrm{IPs}$}

ATP not only evokes the release of $\left[{ }^{3} \mathrm{H}\right] \mathrm{AA}$, but also strongly stimulates the accumulation of $\left[{ }^{3} \mathrm{H}\right] \mathrm{IPs}$ in striatal astrocytes (Stella et al., 1994). However, IL-1 $\beta$ treatment only marginally affected both the efficacy and the potency of ATP in stimulating the accumulation of $\left[{ }^{3} \mathrm{H}\right] \mathrm{IPs}$ (Fig. $2 B$ ).

\section{IL-1 $\beta$ induces the expression of a functional $P_{2 Y 2}$ receptor gene}

To investigate the molecular mechanism involved in the effect of IL- $1 \beta$ on the ATP-evoked release of AA, we first determined whether treatment of astrocytes with the cytokine would induce a modification in the expression of purinoceptors. 
Figure 2. Enhancement by IL-1 $\beta$ of the ATP-evoked release of $\left[{ }^{3} \mathrm{H}\right] \mathrm{AA}$ but not of the evoked accumulation of $\left[{ }^{3} \mathrm{H}\right] \mathrm{IPs}$. Both $\left[{ }^{3} \mathrm{H}\right]$ AA release $(A)$ and $\left[{ }^{3} \mathrm{H}\right] \mathrm{IPs}$ accumulation $(B)$ were estimated in the presence of increasing concentrations of ATP in striatal astrocytes, which were either untreated $(-\mathrm{IL}-1 \beta)$ or treated (+IL-1 $\beta)$ with IL-1 $\beta$ (100 pM) for 22-24 hr, as described in Materials and Methods. Each data point corresponds to the mean \pm SEM of $n=12$ determinations from four independent experiments performed in triplicate and is expressed in percent of the control ATP response measured in the same experiment.
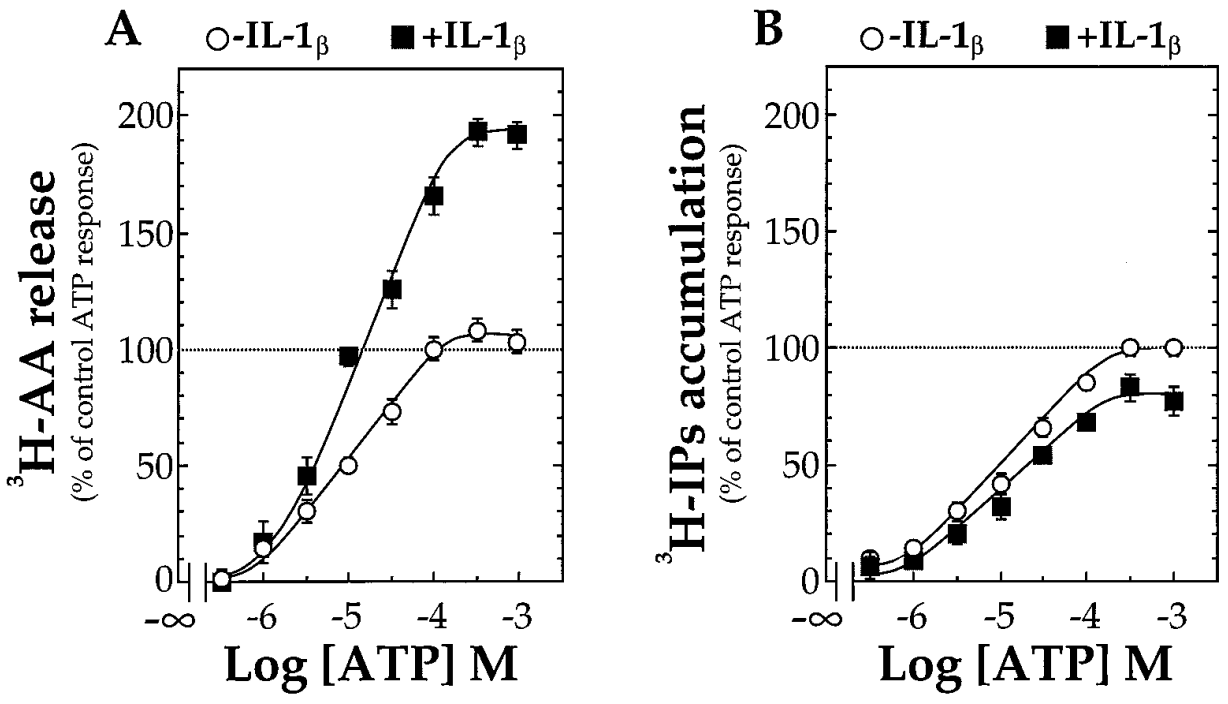

Table 2. Effects of purinoceptor agonists on the release of $\left[{ }^{3} \mathrm{H}\right] \mathrm{AA}$

$\left[{ }^{3} \mathrm{H}\right] \mathrm{AA}$ release

(\% of the control ATP response)

\begin{tabular}{lcll} 
Agents & $\mu \mathrm{M}$ & $-\mathrm{IL}-1 \beta$ & $+\mathrm{IL}-1 \beta$ \\
\hline UTP & 10 & $14 \pm 4$ & $84 \pm 12^{* *}$ \\
$2 \mathrm{MeS}-\mathrm{ATP}$ & 1 & $40 \pm 5$ & $45 \pm 9$
\end{tabular}

Astrocytes were either untreated (-IL-1 $\beta$ ) or treated for $22-24 \mathrm{hr}$ with $100 \mathrm{pm} \mathrm{IL-1 \beta}$ $(+\mathrm{IL}-1 \beta)$. Cells were then incubated for $15 \mathrm{~min}$ with the purinoceptor agonists used at the indicated concentrations. Each data point corresponds to the mean \pm SEM of $n=9$ determinations from three independent experiments performed in triplicate. Data are expressed in percent of the control ATP $(200 \mu \mathrm{M})$-evoked release of AA measured in the same experiments in $-\mathrm{IL}-1 \beta$ cells. ${ }^{* *} p<0.01$ was found when compared with - IL- $1 \beta$ condition (two-tailed unpaired Student's $t$ test).

Treatment of astrocytes with Il- $1 \beta$ changed the efficacy of ATP in releasing $\left[{ }^{3} \mathrm{H}\right] \mathrm{AA}$ but not its potency $\left(\mathrm{EC}_{50} \approx 10 \mu \mathrm{M}\right)$ (Fig. $\left.2 B\right)$. This result suggests that if IL- $1 \beta$ induces the expression of a purinoceptor, this receptor should also be activated by ATP with an $\mathrm{EC}_{50}$ in the $\mu \mathrm{M}$ range. Seven subtypes of $\mathrm{P}_{2 \mathrm{Y}}$ receptors have been identified $\left(\mathrm{P}_{2 \mathrm{Y} 1}\right.$ : Webb et al., 1993; $\mathrm{P}_{2 \mathrm{Y} 2}$ : Lustig et al., 1993; $\mathrm{P}_{2 \mathrm{Y} 3}$ : Webb et al., 1996a; $\mathrm{P}_{2 \mathrm{Y} 4}$ : Communi et al., 1995; Nguyen et al., 1995; $\mathrm{P}_{2 \mathrm{Y} 5}$ : Webb et al., 1996b; $\mathrm{P}_{2 \mathrm{Y} 6}$ : Chang et al., 1995; $\mathrm{P}_{2 \mathrm{Y} 7}$ : Akbar et al., 1996). Among these receptors, solely $\mathrm{P}_{2 \mathrm{Y} 1}$ and $\mathrm{P}_{2 \mathrm{Y} 2}$ receptors are activate by $\mathrm{ATP}$ with an $\mathrm{EC}_{50}$ in the $\mu \mathrm{M}$ range.

We first used a pharmacological approach to investigate whether the expression of $\mathrm{P}_{2 \mathrm{Y} 1}$ or $\mathrm{P}_{2 \mathrm{Y} 2}$ receptors was induced by IL- $1 \beta$ in astrocytes. At present, purinoceptors can only be distinguished by selective agonists, because specific antagonists are not available (Harden et al., 1995). It has been shown that $\mathrm{P}_{2 \mathrm{Y} 1}$ receptors are fully activated by $1 \mu \mathrm{M} 2 \mathrm{MeS}-\mathrm{ATP}$ (Filtz et al., 1994). At $1 \mu \mathrm{M}, 2 \mathrm{MeS}-\mathrm{ATP}$ evoked a significant release of $\left[{ }^{3} \mathrm{H}\right] \mathrm{AA}$ from untreated astrocytes, yet this response was not affected by treating astrocytes with IL- $1 \beta$ (Table 2 ). It has been shown that $\mathrm{P}_{2 \mathrm{Y} 2}$ receptors are fully activated by $10 \mu \mathrm{M}$ UTP (Lustig et al., 1993). At $10 \mu \mathrm{M}$, UTP did not evoke a significant release of $\left[{ }^{3} \mathrm{H}\right] \mathrm{AA}$ from untreated astrocytes, whereas it evoked a strong response in IL- $1 \beta$-treated astrocytes (Table 2 ). These results, although not conclusive, suggest an induced expression in $\mathrm{P}_{2 \mathrm{Y} 2}$ receptors after IL- $1 \beta$ treatment.

To assess whether the expression of $\mathrm{P}_{2 \mathrm{Y} 2}$ receptors was indeed induced in IL- $1 \beta$-treated astrocytes, we performed RT/PCR analysis using specific primers (see Materials and Methods) and as- trocytic cDNA as template. The $396 \mathrm{bp}$ PCR product (isolated, subcloned, and sequenced) corresponding to the N-terminal of the mouse $\mathrm{P}_{2 \mathrm{Y} 2}$ receptor (amino acid 4-136) was detected in astrocytes treated with IL- $1 \beta$ but not in untreated cells (Fig. $3 A$ ).

To prevent the expression of $\mathrm{P}_{2 \mathrm{Y} 2}$ receptors induced by the cytokine treatment, an antisense oligodeoxynucleotide directed against the ATG initiation codon of this receptor was designed $\left(\mathrm{P}_{2 \mathrm{Y} 2}\right.$-AS; see Materials and Methods). Pretreatment of the astrocytes with $\mathrm{P}_{2 \mathrm{Y} 2}$-AS indeed abolished the UTP $(10 \mu \mathrm{M})$-evoked release of $\left[{ }^{3} \mathrm{H}\right] \mathrm{AA}$ observed in IL- $1 \beta$-treated astrocytes (Fig. $3 B$ ). We then addressed the question of whether an induction of $\mathrm{P}_{2 \mathrm{Y} 2}$ receptors could be responsible for the enhanced ATP response observed in IL- $1 \beta$-treated cells. Pretreating astrocytes with $\mathrm{P}_{2 \mathrm{Y}_{2}}$-AS resulted in a significant reduction of the ATP (200 $\mu \mathrm{M})$-evoked release of $\left[{ }^{3} \mathrm{H}\right] \mathrm{AA}$ from IL- $1 \beta$-treated astrocytes but did not alter the ATP response in untreated cells (Fig. $3 B$ ).

As a control in the oligodeoxynucleotide treatment step, we used scrambled oligodeoxynucleotides $\left(\mathrm{P}_{2 \mathrm{Y}_{2}}-\mathrm{SCR}\right)$. Pretreating astrocytes with $\mathrm{P}_{2 \mathrm{Y} 2}$-SCR did not result in a lowering of either the UTP- or the ATP-evoked release of $\left[{ }^{3} \mathrm{H}\right] \mathrm{AA}$ (Fig. 3B). Intriguingly, we observed a nonspecific enhancement of each agonistevoked release of $\left[{ }^{3} \mathrm{H}\right] \mathrm{AA}$ that we studied, this effect being independent of whether astrocytes were treated with IL-1 $\beta$ (Fig. $3 B$ ).

\section{IL-1 $\beta$ treatment enhances the amount of cytosolic PLA}

Is an induction of $\mathrm{P}_{2 \mathrm{Y} 2}$ receptors the sole molecular mechanism responsible for the enhancing effect of IL- $1 \beta$ on the ATP-evoked release of AA from astrocytes? It is known that IL- $1 \beta$ increases the expression of $\mathrm{CPLA}_{2}$ (Lin et al., 1992). Therefore, we measured the release of $\left[{ }^{3} \mathrm{H}\right] \mathrm{AA}$ evoked by a direct stimulation of $\mathrm{cPLA}_{2}$ activity. Receptor-independent-evoked release of $\left[{ }^{3} \mathrm{H}\right] \mathrm{AA}$ can be measured by the concomitant activation of $\mathrm{PKC}$ and the increase in $\left[\mathrm{Ca}^{2+}\right] \mathrm{i}$ (two processes that are involved in the activation of cPLA $_{2}$ ) (Lin et al., 1992, 1993). Treatment of astrocytes with increasing concentrations of IL- $1 \beta$ progressively enhanced the evoked release of $\left[{ }^{3} \mathrm{H}\right] \mathrm{AA}$ induced by the co-application of PMA $(0.1 \mu \mathrm{M})$ and ionomycin $(2 \mu \mathrm{M})$ (Fig. 4). At $100 \mathrm{pm}$, IL-1 $\beta$ enhanced by fourfold the receptor-independent-evoked release of $\left[{ }^{3} \mathrm{H}\right] \mathrm{AA}$.

This enhancing effect of IL- $1 \beta$ on the receptor-independentevoked release of $\left[{ }^{3} \mathrm{H}\right] \mathrm{AA}$ did not result from an increased incor- 
A
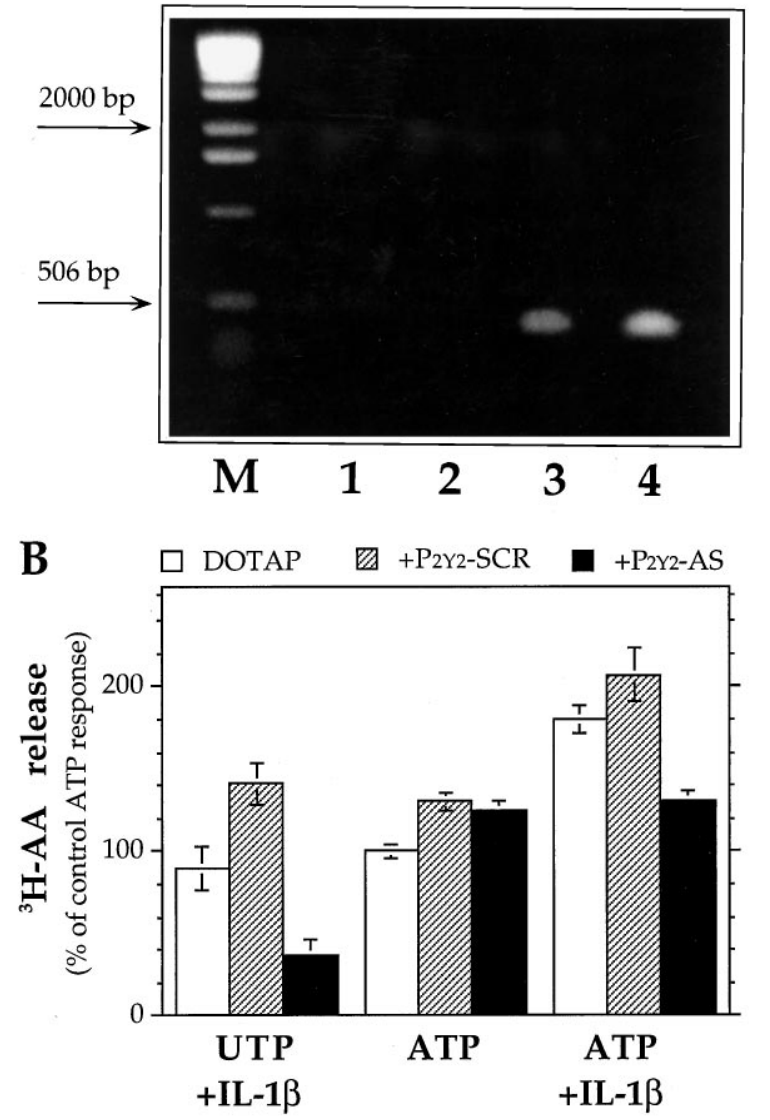

Figure 3. Expression of $\mathrm{P}_{2 \mathrm{Y} 2}$ receptors and inhibitory effect of $\mathrm{P}_{2 \mathrm{Y} 2}$ receptor oligodeoxynucleotides on the IL- $1 \beta$-evoked release of $\left[{ }^{3} \mathrm{H}\right] \mathrm{AA}$ $A$, Total RNA $(0.5 \mu \mathrm{M})$ isolated from untreated or IL- $1 \beta$-treated astrocytes was reverse transcribed, and the recombinant sequence was amplified by PCR using specific mouse $\mathrm{P}_{2 \mathrm{Y} 2}$ receptor primers (see Materials and Methods). Shown is one PCR product repeated three times with similar results. Lane 1 shows the assay in the absence of DNA, lane 2 RNA from untreated astrocytes, lane $3 \mathrm{IL}-1 \beta$-treated astrocytes, lane 4 mouse genomic DNA was used as positive control. $M$, Molecular weight marker. As a control in the RT step, the cDNA corresponding to a phosphoprotein present in astrocytes, PEA-15, was amplified from both untreated and IL-1 $\beta$-treated astrocytes (data not shown) (Estellés et al., 1996). B, Astrocytes were pretreated for $8 \mathrm{hr}$ in the presence of $10 \mathrm{mg} / \mathrm{ml}$ DOTAP and $10 \mu \mathrm{M}$ antisense $\left(\mathrm{P}_{2 \mathrm{Y} 2}-\mathrm{AS}\right)$ or scrambled $\left(\mathrm{P}_{2 \mathrm{Y} 2}-\mathrm{SCR}\right)$ oligonucleotides. Then, cells were either untreated $(-\mathrm{IL}-1 \beta)$ or treated $(+\mathrm{IL}-1 \beta)$ with IL-1 $\beta$ (100 pM) for $22-24 \mathrm{hr} .\left[{ }^{3} \mathrm{H}\right] \mathrm{AA}$ release was estimated in the presence of UTP $(10 \mu \mathrm{M})$ or ATP $(200 \mu \mathrm{M})$ as described in Materials and Methods. Each data point corresponds to the mean \pm SEM of $n=9$ determinations from three independent experiments performed in triplicate and is expressed in percent of the control ATP $(200 \mu \mathrm{M})$-evoked release of AA measured in the same experiment. Further supporting the specificity of oligodeoxynucleotides is the observation showing that $\mathrm{P}_{2 \mathrm{Y} 2}$-AS did not change a receptor-independent-evoked release of $\left[{ }^{3} \mathrm{H}\right] \mathrm{AA}$ resulting from the combined application of PMA $(0.1 \mu \mathrm{M})$ and ionomycin $(2 \mu \mathrm{M})$ in IL- $1 \beta$-treated cells and that $\mathrm{P}_{2 \mathrm{Y} 2}$-SCR had a small nonspecific enhancing effect (data not shown).

poration of $\left[{ }^{3} \mathrm{H}\right] \mathrm{AA}$ into the putative substrates of $\mathrm{CPLA}_{2}$. Indeed, as estimated by TLC, the total incorporation of $\left[{ }^{3} \mathrm{H}\right] \mathrm{AA}$ into the entire phospholipid fraction was not significantly modified by the cytokine treatment (data not shown), nor was its partition in the different phospholipid subclasses: phosphatidylcholine $(30 \pm 1 \%$; $30 \pm 2 \%)$, phosphatidylinositol/phosphatidylserine $(30 \pm 2 \%$; $33 \pm 1 \%)$, phosphatidylethanolamine $(40 \pm 1 \% ; 37 \pm 3 \%)$, in the presence or absence of IL- $1 \beta$, respectively $(n=9)$.

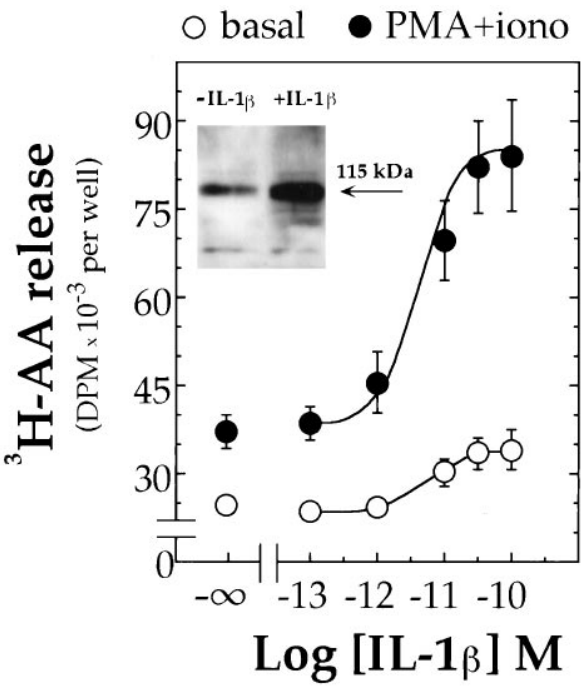

Figure 4. Stimulatory effect of increasing concentrations of IL- $1 \beta$ on the receptor-independent-evoked release of $\left[{ }^{3} \mathrm{H}\right] \mathrm{AA}$ and on the amount of $\mathrm{cPLA}_{2} \cdot\left[{ }^{3} \mathrm{H}\right] \mathrm{AA}$ release was estimated as described in Materials and Methods in either the absence (basal) or the presence of PMA $(0.1 \mu \mathrm{M})+$ ionomycin (iono, $2 \mu \mathrm{M}$ ) from astrocytes treated for 22-24 hr with increasing concentrations of IL- $1 \beta$. Each data point corresponds to the mean \pm SEM of $n=9$ determinations from three independent experiments performed in triplicate. The maximal effective concentration for IL- $1 \beta$ is $\approx 50 \mathrm{pM}$ and its $\mathrm{EC}_{50} \approx 5 \mathrm{pM}$; inset, astrocytes were treated or not treated for 22-24 hr with IL-1 $\beta$ (100 pM). Quantification of the amount of $\mathrm{cPLA}_{2}$ was performed by Western blotting using an anti-cPLA ${ }_{2}$ antibody, as described in Materials and Methods.

Using specific antibodies directed against $\mathrm{cPLA}_{2}$ and subsequent quantification of the immunoreactive bands by computerassisted densitometer, we investigated whether IL-1 $\beta$ treatment could enhance the expression of this enzyme. Indeed, the amount of $\mathrm{cPLA}_{2}$ was increased by 4.5 -fold in astrocytes treated with the cytokine (see Fig. 4, inset).

\section{PKC activity is required in the $P_{2 Y 2}$ receptor-mediated release of $\left[{ }^{3} \mathrm{H}\right] \mathrm{AA}$}

What are the proteins involved in transducing an activation of $\mathrm{P}_{2 \mathrm{Y} 2}$ receptors to a stimulation of $\mathrm{CPLA}_{2}$ activity? Several observations suggest that PKC activity is necessary in the enhanced ATP-evoked release of AA observed in IL- $1 \beta$-treated astrocytes. We found that both staurosporine $(0.2 \mu \mathrm{M}$; data not shown $)$ and the selective PKC inhibitor Ro 31-8220 (3 $\mu \mathrm{M})$ prevented the enhancement of the ATP $(200 \mu \mathrm{M})$-evoked release of $\left[{ }^{3} \mathrm{H}\right] \mathrm{AA}$ (Fig. 5). Also, prolonged application of PMA (1 $\mu \mathrm{M}$ for 22-24 hr) reduced by $81 \pm 4 \%$ the total activity of PKC $(n=9)$ and prevented the enhancing effect of IL-1 $\beta$ on the ATP-evoked response (Fig. 5). This treatment also strongly reduced the UTP $(10 \mu \mathrm{M})$-evoked release of $\left[{ }^{3} \mathrm{H}\right] \mathrm{AA}$ in cytokine-treated cells (Fig. 5). By contrast, in untreated astrocytes, PKC inhibitors or PKC downregulation did not affect or only slightly affected the ATPevoked release of $\left[{ }^{3} \mathrm{H}\right] \mathrm{AA}$ (Fig. 5).

Additional experiments indicated that the PKC dependency of the IL- $1 \beta$ - induced enhancement of the ATP-evoked release of $\left[{ }^{3} \mathrm{H}\right] \mathrm{AA}$ did not result from an upregulation or a mobilization of PKC activity. The cellular repartition of PKC activity (i.e., soluble and particulate fractions) was not changed by the cytokine treatment: (in nanomoles of ${ }^{32} \mathrm{P}$ incorporated during $10 \mathrm{~min}$ incubation per milligram of protein): soluble fraction, $10.9 \pm 0.4$ and 


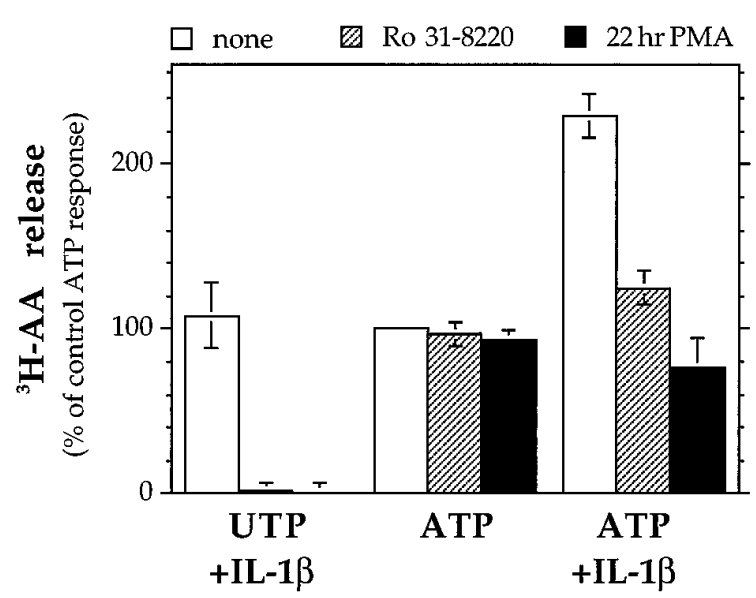

Figure 5. Effect of a PKC inhibitor or long-term PMA treatment on the release of $\left[{ }^{3} \mathrm{H}\right]$ AA evoked by ATP or UTP. Astrocytes were either untreated ( - IL-1 $\beta$ ) or treated (+IL-1 $\beta)$ with IL-1 $\beta(100 \mathrm{pM})$ for $22-24 \mathrm{hr}$ in either the presence or the absence of PMA $(1 \mu \mathrm{M})$, as indicated in Materials and Methods. $\left[{ }^{3} \mathrm{H}\right] \mathrm{AA}$ release was estimated in the presence of ATP $(200 \mu \mathrm{M})$ or UTP $(10 \mu \mathrm{M})$, as described in Materials and Methods. PKC inhibitor Ro 31-8220 (3 $\mu \mathrm{M})$ was present only during the stimulation period. Each data point corresponds to the mean \pm SEM of $n=9$ determinations from three independent experiments performed in triplicate and is expressed in percent of the control ATP $(200 \mu \mathrm{M})$-evoked release of AA measured in the same experiment.

$9.8 \pm 05$; particulate fraction, $4.1 \pm 0.4$ and $5.4 \pm 0.5$ in untreated and IL- $1 \beta$-treated cells, respectively $(n=9)$.

\section{DISCUSSION}

In the present study, we demonstrate that IL- $1 \beta$ modifies the population of functional purinoceptors present on astrocytes. By inducing the expression of $\mathrm{P}_{2 \mathrm{Y} 2}\left(\mathrm{P}_{2 \mathrm{U}}\right)$ receptors, IL-1 $\beta$ enhances the ATP-evoked release of AA. Also, we present evidence showing that stimulation of these newly expressed $\mathrm{P}_{2 \mathrm{Y} 2}$ receptors by ATP enhances $\mathrm{CPLA}_{2}$ activity in a PKC-dependent manner.

$\mathrm{P}_{2 \mathrm{Y} 2}$ receptors appear to be absent in untreated astrocytes. In support of this conclusion, it was observed that (1) a concentration of UTP shown to be maximally effective on cells expressing the $\mathrm{P}_{2 \mathrm{Y} 2}$ receptor cDNA (i.e., $10 \mu \mathrm{M}$ ) (see Lustig et al., 1993; Erb et al., 1995) was without effect on the release of AA from untreated astrocytes (Table 2); (2) exposure of untreated astrocytes to $\mathrm{P}_{2 \mathrm{Y} 2}$-AS oligodeoxynucleotides did not affect the ATP-evoked release of AA (Fig. $3 B$ ); and (3) in four independent PCR reactions, we were never able to amplify $\mathrm{P}_{2 \mathrm{Y} 2}$ mRNA (Fig. $3 A$ ). These results suggest that expression of the $\mathrm{P}_{2 \mathrm{Y} 2}$ receptor gene is under the control of a promotor induced by the signaling pathway coupled to an activation of IL-1 receptors.

Expression of functional $\mathrm{P}_{2 \mathrm{Y} 2}$ receptors in IL- $1 \beta$-treated cells may not be solely responsible for the enhancement of the ATPevoked release of $\mathrm{AA}$, because a marked increase in the amount of cPLA $_{2}$ was also detected in our experiments. This result is in agreement with those obtained in both glioma cells and fibroblasts treated with the cytokine (Lin et al., 1992; Ozaki et al., 1994). The IL-1 $\beta$ treatment increased fourfold the release of AA stimulated by application of PMA and ionomycin. This effect was associated with a similar fourfold increase in the amount of $\mathrm{CPLA}_{2}$ (Fig. 4). Previous studies have demonstrated that $\mathrm{CPLA}_{2}$ is activated by PKC (Lin et al., 1993). Because downregulation and inhibition of PKC activity abolished both the UTP-evoked release of AA and the enhancement of the ATP response in IL- $1 \beta$-treated astrocytes
(Fig. 5), it seems likely that both agonists bind to the newly synthesized $\mathrm{P}_{2 \mathrm{Y} 2}$ receptors, which subsequently activate $\mathrm{CPAA}_{2}$ in a PKC-dependent manner. On the other hand, the ATP-evoked release of AA from untreated astrocytes could involve other types of $\mathrm{PLA}_{2}$ isoenzymes, because this process did not depend on PKC activity (Fig. 5).

What is the physiopathological relevance of these results? It has been shown that during acute brain inflammation (such as that which occurs in cerebral ischemia and traumatic brain injury) or during chronic neurodegeneration (amyotrophic lateral sclerosis and scrapie), invading macrophages or microglia are activated and produce IL-1 $\beta$ (for review, see Perry et al., 1995). IL-1 $\beta$ can, in turn, activate IL-1 receptors on astrocytes and induce gene expression. We have shown here that IL- $1 \beta$ reveals a functional signaling pathway at the $\mathrm{P}_{2 \mathrm{Y} 2}$ receptor, which results in an increase of the ATP-evoked release of AA. In previous studies performed on striatal astrocytes, we have shown that glutamate also evokes AA release and that a synergistic response is observed when glutamate is applied together with ATP (Stella et al., 1994). Such synergistic response is enhanced further by IL- $1 \beta$ (our unpublished observations). Therefore, the combined release of IL-1 $\beta$ from inflammatory cells and of glutamate and ATP from nerve terminals may cause a dramatic increase in the levels of nonesterified AA.

Free AA decreases glutamate reuptake by astrocytes and neurons (Yu et al., 1986; Barbour et al., 1989). Because both ATP and glutamate evoke the release of AA (see also Dumuis et al., 1988, 1990; Lazarewicz et al., 1988), it is possible that the combined actions of these neurotransmitter and IL- $1 \beta$ may constitute a feedforward mechanism that enhances the extracellular concentrations of glutamate. In support of this hypothesis are studies showing that extracellular concentrations of glutamate are increased during cerebral ischemia, a response linked to AA formation (Bazan, 1970; Katchman and Hershkowitz, 1994).

High levels of free AA can cause neuronal damage either directly (Okuda et al., 1994) or by enhancing glutamate-mediated toxicity (Choi, 1988; Miller et al., 1992). Because the levels of both glutamate and ATP may be further enhanced as a consequence of cell death (Gordon, 1986), the concomitant presence of high levels of these molecules may again constitute a feedforward mechanism, which compromises neuro-astrocytic interactions and leads to neuronal death. Finally, IL- $1 \beta$ has also been shown to perturb the finely tuned energy supply from astrocytes to neurons, i.e., by enhancing glucose uptake into astrocytes, a process that may render neurons more prone to neurodegeneration (Yu et al., 1995) (for review, see Magistretti et al., 1995).

Together, these lines of evidence suggest that during inflammatory conditions in the brain, glutamate, ATP, and IL- $1 \beta$ may cooperate in enhancing the release of AA. They may in turn aggravate glutamate neurotoxicity, establishing a feedforward mechanism that may contribute to cerebral tissue damage and neuronal death.

\section{REFERENCES}

Abbracchio MP, Saffrey MJ, Höpker V, Burnstock G (1994) Modulation of astroglial cell proliferation by analogues of adenosine and ATP in primary cultures of rat striatum. Neuroscience 59:67-76.

Akbar MGK, Dasari RV, Webb TE, Ayyanathan K, Pillarisetti K, Sandhu AK, Athwal RS, Daniel JL, Ashby B, Barnard EA, Kunapuli SP (1996) Molecular cloning of a novel $\mathrm{P} 2$ purinoceptor from human erythroleukemia cells. J Biol Chem 271:18363-18367.

Ban EM, Sarliève LL, Haour FG (1993) Interleukin-1 binding sites on astrocytes. Neuroscience 52:725-733. 
Barbour B, Szatkowski M, Ingledew N, Attwell D (1989) Arachidonic acid induces a prolonged inhibition of glutamate uptake into glial cells. Nature 342:918-920.

Bazan NG (1970) Effects of ischemia and electroconvulsive shock on fatty acid pool in the brain. BBA 218:1-10.

Bennet C, Chiang M-Y, Chan H, Shoemaker J, Mirabelli C (1992) Cationic lipids enhance cellular uptake and activity of phosphorothioate antisense oligonucleotides. Mol Pharmacol 41:1023-1033.

Benveniste EN, Sparacio SM, Norris JG, Grenett HE, Fuller GM (1990) Induction and regulation of interleukin- 6 gene expression in rat astrocytes. J Neuroimmunol 30:201-212.

Bradford MM (1976) A rapid and sensitive method for the quantitation of microgram quantities of protein utilizing the principle of protein-dye binding. Annu Rev Biochem 72:248-254.

Bruner G, Murphy S (1990) ATP-evoked arachidonic acid mobilization in astrocytes is via a P2y-purinergic receptor. J Neurochem 55:1569-1575.

Cameron RS, Rakic P (1991) Glial cell lineage in the cerebral cortex: a review and synthesis. Glia 4:124-137.

Capaccioli S, Di Pasquale G, Mini E, Mazzei T, Quattrone A (1993) Cationic lipids improve antisense oligonucleotide uptake and prevent degradation in cultured cells and human serum. Biochem Biophys Res Commun 197:812-825.

Chang K, Hanaoka K, Kumada M, Takuwa Y (1995) Molecular cloning and functional analysis of a novel P2 nucleotide receptor. J Biol Chem 270:26152-26158.

Choi DW (1988) Glutamate neurotoxicity and diseases of the nervous system. Neuron 1:623-634.

Chomczynski P, Sacchi N (1987) Single step method of RNA isolation by acid guanidium thyocyanate phenol chloroform extraction. Annu Rev Biochem 162:156-159.

Christjanson LJ, Middlemiss PJ, Rathbone MP (1993) Stimulation of astrocyte proliferation by purine and pyrimidine nucleotides and nucleosides. Glia 7:176-182.

Clark JD, Lin L-L, Kriz RW, Ramesha CS, Sultzman LA, Lin AY, Milona N, Knopf JL (1991) A novel arachidonic acid-selective cytosolic PLA2 contains a $\mathrm{Ca}^{++}$-dependent translocation domain with homology to PKC and GAP. Cell 65:1043-1051.

Communi D, Pirotton S, Parmentier M, Boeynaems J-M (1995) Cloning and functional expression of a human uridine nucleotide receptor. J Biol Chem 270:30849-30852.

Das S, Potter H (1995) Expression of the Alzheimer amyloid-promoting factor antichymotrypsin is induced in human astrocytes by IL-1. Cell 14:447-456.

Delumeau J-C, Tencé M, Marin P, Cordier J, Glowinski J, Prémont J (1991) Synergistic regulation of cytosolic $\mathrm{Ca} 2+$ concentration by adenosine and $\alpha 1$-adrenergic agonists in mouse striatal astrocytes. Eur J Neurosci 3:539-550.

Dinarello CA (1994) The interleukin-1 family: 10 years of discovery. FASEB J 8:1314-1325.

Dumuis A, Sebben M, Haynes L, Pin J-P, Bockaert J (1988) NMDA receptors activate the arachidonic acid cascade system in striatal neurons. Nature 336:68-70.

Dumuis A, Pin J-P, Oomagari K, Sebben M, Bockaert J (1990) Arachidonic acid released from striatal neurons by joint stimulation of ionotropic and metabotropic quisqualate receptors. Nature 347:182-184.

Edwards FA, Gibbs AJ, Colquhoun D (1992) ATP receptor-mediated synaptic currents in the central nervous system. Nature 359:144-147.

El-Etr M, Cordier J, Glowinski J, Prémont J (1989) A neuroglial cooperativity is required for the potentiation by 2-chloroadenosine of the muscarinic-sensitive phospholipase $\mathrm{C}$ in the striatum. J Neurosci 9:1473-1480.

Enkvist MOK, McCarthy KD (1992) Activation of protein kinase C blocks astroglial gap junction communication and inhibits the spread of calcium waves. J Neurochem 59:519-526.

Erb L, Garrad R, Wang Y, Quinn T, Turner JT, Weisman GA (1995) Site-directed mutagenesis of P2U purinoceptors. J Biol Chem 270:4185-4188.

Estellés A, Yokoyama M, Nothias F, Vincent J-D, Glowinski J, Vernier P, Chneiweiss H (1996) The major astrocytic phosphoprotein PEA-15 is encoded by two mRNAs conserved on their full length in mouse and human. J Biol Chem 271:14800-14806.

Evans RJ, Derkach V, Surprenant A (1992) ATP mediates fast synaptic transmission in mammalian neurons. Nature 357:503-505.

Filtz TM, Li Q, Boyer JL, Nicholas RA, Harden TK (1994) Expression of a cloned P2Y purinergic receptor that couples to phospholipase C. Mol Pharmacol 46:8-14.

Fredholm BB, Abbracchio MP, Burnstock G, Daly JW, Harden KT, Jacobson KA, Leff P, Williams M (1994) Nomenclature and classification of purinoceptors. Pharmacol Rev 46:143-156.

Frei K, Siepl C, Groscurth P, Bodmer S, Schwerdel C, Fontana A (1987) Antigen presentation and tumor cytotoxicity by interferon- $\gamma$-treated microglia cells. Eur J Immunol 17:1271-1278.

Galligan JJ, Bertrand PP (1994) ATP mediates fast synaptic potentials in enteric neurons. J Neurosci 14:7563-7571.

Gebicke-Haerter PJ, Wurster S, Schobert A, Hertting G (1988) P2purinoceptor induced prostaglandin synthesis in primary rat astrocyte cultures. Naunyn Schmiedebergs Arch Pharmacol 338:704-707.

Giulian D, Baker TJ, Shih L-CN, Lachman LB (1986) Interleukin-1 of the central nervous system is produced by ameboid microglia. J Exp Med 164:594-604.

Gordon JL (1986) Extracellular ATP: effects, source and fate. Biochem J 233:309-319.

Hannum CH, Wilcox CJ, Arend WP, Joslin FG, Dripps DJ, Heimdal PL, Armes LG, Sommer A, Eisenberg SP, Thompson RC (1990) Interleukin-1 receptor antagonist activity of a human interleukin-1 inhibitor. Nature 343:336-340.

Harden TK, Boyer JL, Nicholas RA (1995) P2-purinergic receptors: subtype-associated signaling responses and structure. In: Annual review of pharmacology and toxicology (AK Cho, Blaschke TF, Loh HH, Way JL, eds), pp 541-579. Palo Alto, CA.

Hertier E, Ayala J, Denèffle P, Bousseau A, Rouget P, Mallat M, Prochiantz A (1988) Brain macrophages synthesize interleukin-1 and interleukin-1 mRNAs in vitro. J Neurosci Res 21:391-397.

Kastritsis CHC, Salm AK, McCarthy KD (1992) Stimulation of the P2y purinergic receptor on type 1 astroglia results in inositol phosphate formation and calcium mobilization. J Neurochem 58:1277-1284.

Katchman AN, Hershkowitz N (1994) Arachidonic acid participates in the anoxia-induced increase in mEPSC frequency in CA1 neurons of the rat hippocampus. Neurosci Lett 168:217-220.

Katsuura G, Gottschall PE, Dahl RR, Arimura A (1989) Interleukin-1 $B E T A$ increases prostaglandin E2 in rat astrocyte cultures: modulatory effect of neuropeptides. Endocrinology 124:3125-3127.

Laemmli UK (1970) Cleavage of structural proteins during assembly of the head of bacteriophage T4. Nature 227:680-685.

Lazarewicz JW, Wroblewski JT, Palmer ME, Costa E (1988) Activation of $N$-methyl-D-aspartate-sensitive glutamate receptors stimulates arachidonic acid releases in primary cultures of cerebellar granule cells. Neuropharmacology 27:765-769.

Lin L-L, Lin AY, DeWitt DL (1992a) Interleukin-1 $\alpha$ induces the accumulation of cytosolic phospholipase A2 and the release of prostaglandin E2 in human fibroblasts. J Biol Chem 267:23451-23454.

Lin L-L, Lin AY, Knopf JL (1992b) Cytosolic phospholipase A2 is coupled to hormonally regulated release of arachidonic acid. Proc Natl Acad Sci USA 89:6147-6151.

Lin L-L, Wartmann M, Lin AY, Knopf JL, Seth A, Davis RJ (1993) cPLA2 is phosphorylated and activated by MAP kinase. Cell 72:269-278.

Lustig KD, Shiau AK, Brake AJ, Julius D (1993) Expression cloning of an ATP receptor from mouse neuroblastoma cells. Proc Natl Acad Sci USA 90:5113-5117.

Magistretti PJ, Pellerin L, Martin J-L (1995) Brain energy metabolism: an integrated cellular perspective. In: Psychopharmacology (FEBDJ Kupfer, ed), pp 657-670. New York: Raven.

Marin P, Stella N, Cordier J, Glowinski J, Prémont J (1993) Role of arachidonic acid and glutamate in the formation of inositol phosphates induced by noradrenalin in striatal astrocytes. Mol Pharmacol 44:1176-1184.

Miller B, Sarantis M, Traynelis SF, Attwell D (1992) Potentiation of NMDA receptor currents by arachidonic acid. Nature 355:722-725.

Neary JT, Whittemore SR, Zhu Q, Norenberg MD (1994) Synergistic activation of DNA synthesis in astrocytes by fibroblast growth factors and extracellular ATP. J Neurochem 63:490-494.

Negro A, Tavella A, Facci L, Callegaro L, Skaper SD (1992) Interleukin- $1 \beta$ regulates proenkephalin gene expression in astrocytes cultured from rat cortex. Glia 6:206-212.

Nguyen T, Erb L, Weisman GA, Marchese A, Heng HHQ, Garrad RC, George SR, Turner JT, O'Dowd BF (1995) Cloning, expression, and chromosomal localization of the human uridine nucleotide receptor gene. J Biol Chem 270:30845-30848. 
Oka S, Arita H (1991) Inflammatory factors stimulate expression of group II phospholipase A2 in rat cultured astrocytes. J Biol Chem 266:9956-9960.

Okuda S, Saito H, Katsuki H (1994) Arachidonic acid: toxic and trophic effects on cultured hippocampal neurons. Neuroscience 63:691-699.

Ozaki M, Morii H, Qvist R, Watanabe Y (1994) Interleukin-1 $\beta$ induces cytosolic phospholipase A2 gene in rat C6 glioma cell line. Biochem Biophys Res Commun 205:12-17.

Pearce B, Murphy S, Jeremy J, Morrow C, Dandona P (1989) ATPevoked $\mathrm{Ca} 2+$ mobilization and prostanoid release from astrocytes: P2-purinergic receptors linked to phosphoinositide hydrolysis. J Neurochem 52:971-977.

Perry HV, Bell MD, Brown HC, Matyszak MK (1995) Inflammation in the nervous system. Curr Opin Neurobiol 5:636-641.

Perry VH, Andersson P-B, Gordon S (1993) Macrophages and inflammation in the central nervous system. Trends Neurosci 16:268-273.

Richardson PJ, Brown SJ (1987) ATP release from affinity-purified rat cholinergic nerve terminals. J Neurochem 48:622-630.

Salter MW, Hicks JL (1994) ATP-evoked increases in intracellular calcium in neurons and glia from the dorsal spinal cord. J Neurosci 14:1563-1575.

Sims JE, March CJ, Cosman D, Widmer MB, MacDonald HR, McMahan CJ, Grubin CE, Wignall JM, Jackson JL, Call SM, Friend D, Alpert AR, Gillis S, Urdal DL, Dower SK (1988) cDNA expression cloning of the IL-1 receptor, a member of the immunoglobulin superfamily. Science 241:585-589.

Smith PK, Krohn RI, Hermanson GT, Mallia AK, Gartner FH, Provenzano MD, Fujimoto EK, Goeke NM, Olson BJ, Klenk DC (1985) Measurement of protein using bicinchoninic acid. Annu Rev Biochem 150:76-85.

Sorg O, Pellerin L, Stolz M, Beggah S, Magistretti PJ (1995) Adenosine triphosphate and arachidonic acid stimulate glycogenolysis in primary cultures of mouse cerebral cortical astrocytes. Neurosci Lett 188:109-112.

Stella N, Tencé M, Glowinski J, Prémont J (1994a) Glutamate induces the release of arachidonic acid by interacting with an atypical metabotropic receptor present on mouse brain astrocytes. Renal Physiol Biochem 17:153-156.
Stella N, Tencé M, Glowinski J, Prémont J (1994b) Glutamate-evoked release of arachidonic acid from mouse brain astrocytes. J Neurosci 14:568-575.

Théry C, Stanley ER, Mallat M (1992) Interleukin 1 and tumor necrosis factor- $\alpha$ stimulate the production of colony-stimulating factor 1 by murine astrocytes. J Neurochem 59:1183-1186.

Towbin H, Staehlin T, Gordon J (1979) Electrophoretic transfer of proteins from polyacrylamide gels to nitrocellulose sheets: procedure and some applications. Proc Natl Acad Sci USA 76:4350-4354.

Webb TE, Simon J, Krishek BJ, Bateson AN, Smart TG, King BF, Burnstock G, Barnard EA (1993) Cloning and functional expression of a brain G-protein-coupled ATP receptor. FEBS Lett 324:219-225.

Webb TE, Henderson D, King BF, Wang S, Simon J, Bateson AN, Burnstock G, Barnard EA (1996a) A novel G protein-coupled P2 purinoceptor (P2Y3) activated preferentially by nucleoside diphosphates. Mol Pharmacol 50:258-265.

Webb TE, Kaplan MG, Barnard EA (1996b) Identification of 6H1 as a P2Y purinoceptor: P2Y5. Biochem Biophys Res Commun 219: $105-110$.

Woodroofe MN, Sarna GS, Wadhwa M, Hayes GM, Loughlin AJ, Tinker A, Cuzner ML (1991) Detection of interleukin-1 and interleukin-6 in adult rat brain, following mechanical injury, by in vivo microdialysis: evidence of a role for microglia in cytokine production. J Neuroimmunol 33:227-236.

Yamamoto K, Miwa T, Ueno R, Hayaishi O (1988) Muramyl dipeptideelicited production of PGD2 from astrocytes in culture. Biochem Biophys Res Commun 156:882-888.

Yu ACH, Chan PH, Fishman RA (1986) Effects of arachidonic acid on glutamate and $\gamma$-aminobutyric acid uptake in primary cultures of rat cerebral cortical astrocytes and neurons. J Neurochem 47:1181-1189.

Yu N, Maciejewski-Lenoir D, Bloom FE, Magistretti PJ (1995) Tumor necrosis factor- $\alpha$ and interleukin- $1 \alpha$ enhance glucose utilization by astrocytes: involvement of phospholipase A2. Mol Pharmacol 48:550-558.

Zimmermann H (1994) Signalling via ATP in the nervous system. Trends Neurosci 17:420-426. 